\begin{tabular}{|l|l|l|l} 
Int.J.Curr.Microbiol.App.Sci (2020) 9(2): 1137-1143 \\
$\begin{array}{l}\text { International Journal of Current Microbiology and Applied Sciences } \\
\text { ISSN: 2319-7706 Volume } 9 \text { Number } 2(2020) \\
\text { Journal homepage: http://www.ijcmas.com }\end{array}$ \\
$\begin{array}{l}\text { EXCELLENT } \\
\text { PUBLISHERS }\end{array}$
\end{tabular}

Original Research Article

https://doi.org/10.20546/ijcmas.2020.902.133

\title{
Genetic Variability Parameters for Yield and Yield Related Traits in Rice (Oryza sativa L.) under Irrigated and Drought Stress Condition
}

\author{
Sadia Perween ${ }^{1}$, Anand Kumar ${ }^{1 *}$, S. P. Singh ${ }^{1}$, Satyendra1, \\ Mankesh Kumar ${ }^{1}$ and Ravi Ranjan Kumar ${ }^{2}$ \\ ${ }^{1}$ Department of Plant Breeding and Genetics, ${ }^{2}$ Department of Molecular Biology \& \\ Biotechnology, Bihar Agricultural University, Sabour (Bhagalpur)-813210, Bihar, India \\ *Corresponding author
}

Keywords

Rice, Drought stress, Genetic

variability and grain yield

Article Info

Accepted:

08 January 2020

Available Online:

10 February 2020

\section{A B S T R A C T}

The present investigation was carried out at rice research farm ofBihar Agricultural University, Sabour (Bhagalpur), Bihar in kharif, 2019 to assess the extent of genetic variability for yield and yield related traits and to estimate heritability and genetic advance in rice genotypes for drought tolerance. The analysis of variance revealed highly significant variation among the genotypes for all the traits studied, under both the environments. The maximum phenotypic and genotypic variance was exhibited by the traits viz., leaf area and root biomass under both the environments. The heritability was recorded high for number of fertile grains per panicle, total number of spikelets per panicle, panicle density index, 1000 grain weight, leaf area, relative water content, proline content, root biomass and grain yield per plant across the environments. High heritability coupled with high genetic advance over mean was observed for fertile grains per panicle, total grains per panicle, panicle density index, leaf area and root biomass in irrigated as well as in stress condition suggesting that direct selection of these characters may be useful for future improvement of genotypes under respective environments along with improvement in drought tolerance and grain yield.

\section{Introduction}

Rice (Oryza sativa L.) is the most important food crop and a primary food source for more than one third of the world's population. It is a self pollinated crop belonging to Poaceae family with a genome size of $430 \mathrm{mb}$ and diploid $(2 n=2 x=24)$. A successful breeding program depends on the genetic diversity of crop to achieve the goals of improving the crop and producing high yielding varieties (Padulosi, 1993). Drought is a major abiotic stress that causes severe yield loss in rice, a staple food crop, affecting 20 per cent of the total rice growing area in Asia. Grain yield is a complex polygenic quantitative trait, greatly affected by environment and determined by the magnitude and nature of their genetic 
variability. Genetic variability, which is due to the genetic differences among individuals within a population, is the core of plant breeding because proper management of diversity can produce permanent gain in the performance of plant and can buffer against seasonal fluctuations. Genetic variability among traits is important for breeding and selecting desirable types. The low heritability of grain yield characters made selection for high yielding varieties possible usually using various components traits associated with yield. However, information on relationship of grain yield and yield contributing traits for rice is not sufficiently available. In view of the above gaps, the present study was undertaken to investigate the genetic variability, heritability and genetic advance for yield related traits as a basis for selection of high yielding rice genotypes. Hence, the present study aims at the assessment of the extent of genetic variability for yield and yield related traits and estimation of heritability and genetic advance in rice genotypes.

\section{Materials and Methods}

A set of forty eight rice genotypes including two checks viz.,Sahbagidhanand Sabour Deep were evaluated at reproductive stage under irrigated and drought stress condition during kharif 2019 in RBD design at Rice Research Farm of Bihar Agricultural University, Sabour, Bhagalpur, Bihar,in randomized block design with three replications. All the recommended package of practices for rice was followed to raise a healthy crop. Data were recorded on five randomly and competitive plants of each genotype from each replications for nineteen characters viz. days to $50 \%$ flowering, days to maturity, number of effective tillers per hill, plant height $(\mathrm{cm})$, panicle length $(\mathrm{cm})$, number of fertile grains per panicle, spikelet sterility (\%), panicle density index, total number of spikelet per panicle, 1000 grain weight $(\mathrm{g})$, grain yield per plant $(\mathrm{g})$, biological yield $(\mathrm{g})$, harvest index (\%), proline content, chlorophyll index, canopy temperature, leaf area, relative water content and root biomass. Data on days to $50 \%$ flowering and days to maturity were recorded on plot basis. Heritability (broadsense) was estimated according to Hanson et al(1956). Phenotypic and genotypic coefficients of variation were estimated as per Burton (1952). Genetic advance as percent of mean was estimated according to Johnson et al (1955).

\section{Results and Discussion}

The analysis of variance revealed that there was highly significant variation among the genotypes for all the traits studied under both the environmentsviz., irrigated and drought stress (Table-1). This in turn indicated that there was sufficient variability in the material studied, under both drought stress and irrigated condition, which could be utilized in further breeding programme. In other words, further analysis of drought tolerance is meaningful as indicated by significant mean sum of squares under drought stress condition. Interestingly, the magnitude of mean sum of square of almost all the traits were more under drought stress condition than irrigated, which indicated directly that the amount of variation for these traits was more desirable under drought stress condition. More variation under drought stress condition is expected as different genotypes respond differentially under drought stress condition. These findings are in accordance with the result of Chen et al., (2001), Pantuwan et al., (2002), Muthuswamy and Kumar (2006), Ouk et al., (2006), Ganapathy et al., (2007), Allah (2009), Mina et al., (2011), Gomez et al., (2003), they reported high variability for different traits in rice. Thus, it implied that there was reasonably sufficient variability in material used for the study, which provides 
ample scope for selecting superior genotypes by the plant breeder for further improvement. The phenotypic variances for all the traits under study were higher than the genotypic variances (El-Kareem and El-Saidy, 2011).This may be due to the non-genetic factor which played an important role in the manifestation of these characters. Wide ranges of variance (phenotypic \& genotypic) were observed in the experimental material for all the traits under investigation in both environments. The maximum phenotypic and genotypic variance was exhibited by the traits viz., leaf area and root biomass under both environments. These findings were in accordance of Mina et al., (2011), Blum et al., (1999) and Manickavelu et al., (2006) who also observed high variance for yield and yield component traits among rice genotypes. The leaf area and root biomass exhibited high genotypic and phenotypic variance in drought stress condition indicating importance of these characters in drought stress condition for further improvement. Similar results were obtained by Chen et al., (2001); Lonbani and Arzani (2011).

The assessment of heritable and non-heritable components in the total variability observed is indispensable in adoption of suitable breeding procedure. The heritable portion of the overall observed variation can be ascertained by studying the components of variation such as GCV, PCV, heritability and genetic advance as per cent of mean. In the present investigation, a higher estimate of genotypic coefficient of variation was noticed for number of sterile grains per panicle, leaf area and root biomass. This is an indicative of less amenability of these traits to environmental fluctuations and hence, greater emphasis should be given to these characters while breeding cultivars from the present material.

Moderate estimate of PCV was observed for effective tillers per hill, number of fertile grains per panicle, total number of spikelets per panicle, panicle density index, biological yield and grain yield per plant in irrigated as well asdrought stress condition. However, plant height, 1000 grain weight and harvest index $\%$ had moderate PCV under drought stress condition. GCV under both conditions varied moderately for number of fertile grains per panicle, total number of spikelets per panicle and panicle density index. However, number of effective tillers per hill in irrigated condition and grain yield per plant in drought stress condition showed moderate GCV and the remaining traits showed low estimates of phenotypic and genotypic coefficient of variation. Similar results have been reported by Sarvanan and Senthil (1997)and Ganapathy et al., (2007). These findings clearly indicated that selecting genotypes through these traits will be effective for drought tolerance. It is interesting to note that the differences between GCV and PCV values were minimum implying least influence of environment and preponderances of additive gene effects; indicating genotypes can be improved and selected for these characters under drought stress condition for improvement of drought tolerance. Study of per se performance of individual genotype suggests the importance of the materials under study and it becomes first-hand information for the breeders. The mean (Kour and Pradhan, 2016) of different quantitative characters including grain yield as performed by the available genotypes suggested that selection of desirable genotypes based on the traits from materials evaluated, can be effective.

In crop improvement programme, selection is practiced directly or indirectly. Selection parameters include the study of heritability and genetic advance (direct selection parameters) and correlation between yield and component traits and path coefficient analysis (indirect selection parameters). In this study, 
heritability in broad sense was found to be high for number of fertile grains per panicle, total number of spikelets per panicle, panicle density index, 1000 grain weight, leaf area, relative water content, proline content, root biomass and grain yield per plant across the environments(drought stress and irrigated condition). These findings are in agreement with the findings of Venkataramana and Shailaja (1999) for grain yield per plant; Wu et al., (2004) for relative water content; Muthuswamy et al., (2006) for number of grains per panicle and grain yield per plant; Manickavelu et al., (2006) for leaf drying at vegetative stage and relative water content; Allah (2009) for days to fifty per cent flowering, number of grains per panicle and seed yield per plant also reported high heritability for relative water content.

Table.1 Analysis of variance for nineteen characters in forty eight rice genotypes under irrigated (irrigated) and stress condition

\begin{tabular}{|c|c|c|c|c|c|c|c|}
\hline \multirow{4}{*}{$\begin{array}{c}\text { S. } \\
\text { No. }\end{array}$} & \multirow[t]{4}{*}{ CHARACTERS } & \multicolumn{6}{|c|}{ MEAN SUM of SQUARES } \\
\hline & & \multicolumn{2}{|c|}{ Replication } & \multicolumn{2}{|c|}{ Treatment } & \multicolumn{2}{|c|}{ Error } \\
\hline & & \multicolumn{2}{|c|}{$(\mathrm{df}=02)$} & \multicolumn{2}{|c|}{$(\mathrm{df}=47)$} & \multicolumn{2}{|c|}{$(\mathrm{df}=94)$} \\
\hline & & Irrigated & Stress & Irrigated & Stress & Irrigated & Stress \\
\hline 1 & Days to $50 \%$ flowering & 10.54 & 12.79 & $18.191 * *$ & $18.454 * *$ & 7.32 & 7.15 \\
\hline 2 & Days to maturity & 5.15 & 2.31 & $23.786 * *$ & $23.106 * *$ & 13.61 & 5.55 \\
\hline 3 & Effective tillers per hill & 1.79 & 0.17 & $3.359 * *$ & $1.624 * *$ & 0.35 & 0.42 \\
\hline 4 & Plant height $(\mathrm{cm})$ & 88.73 & 112.75 & $157.206 * *$ & $208.411 * *$ & 32.68 & 62.89 \\
\hline 5 & Panicle length $(\mathrm{cm})$ & 0.49 & 0.98 & $7.527 * *$ & $9.056 * *$ & 2.01 & 2.17 \\
\hline 6 & No. of fertile grains/ panicle & 53.24 & 495.58 & $1128.890 * *$ & $581.411 * *$ & 91.29 & 47.55 \\
\hline 7 & No. of sterile grains/ panicle & 1.01 & 7.79 & $92.410 * *$ & $133.375 * *$ & 3.30 & 4.69 \\
\hline 8 & Sterility (\%) & 1.96 & 29.36 & $40.423 * *$ & $61.311 * *$ & 2.28 & 3.16 \\
\hline 9 & Total no. of spikelets panicle ${ }^{-1}$ & 41.47 & 386.54 & $1318.710 * *$ & $868.453 * *$ & 92.34 & 51.45 \\
\hline 10 & Panicle density index & 0.18 & 0.89 & $1.972 * *$ & $1.353 * *$ & 0.23 & 0.19 \\
\hline 11 & 1000 -grain weight (g) & 1.15 & 3.00 & $13.919 * *$ & $11.699 * *$ & 1.38 & 1.83 \\
\hline 12 & Biological yield (g) & 14.88 & 17.06 & $45.945^{* *}$ & $32.791 * *$ & 12.07 & 12.77 \\
\hline 13 & Harvesting Index (\%) & 9.73 & 16.74 & $19.097 * *$ & $56.939 * *$ & 11.05 & 23.83 \\
\hline 14 & Grain yield/ plant (g) & 2.89 & 4.65 & $20.919 * *$ & $13.202 * *$ & 3.58 & 1.47 \\
\hline 15 & Leaf area $\left(\mathrm{cm}^{2}\right)$ & 13.15 & 0.72 & $110.514 * *$ & 120.04 & 2.99 & 1.72 \\
\hline 16 & Relative Water Content (\%) & 1.59 & 0.37 & $46.047 * *$ & $39.526 * *$ & 2.98 & 0.65 \\
\hline 17 & Proline & 1.46 & 2.71 & $7.246 * *$ & $7.464 * *$ & 0.31 & 0.48 \\
\hline 18 & Root biomass (g) & 1.36 & 1.45 & $66.496 * *$ & $29.590 * *$ & 3.50 & 1.94 \\
\hline 19 & Chlorophyll Index & 9.77 & 0.20 & $26.627 * *$ & $13.903 * *$ & 12.69 & 2.67 \\
\hline
\end{tabular}

$*$ and $* *$ significant at $5 \%$ and $1 \%$ probability level, respectively. 
Table.2 Estimation of genetic parameters of variability for nineteen characters in rice under irrigated and stress conditions

\begin{tabular}{|c|c|c|c|c|c|c|c|c|c|c|c|c|c|c|c|}
\hline \multirow[t]{2}{*}{$\begin{array}{l}\text { Sl } \\
\text { no. }\end{array}$} & \multirow[t]{2}{*}{ Characters } & \multicolumn{2}{|c|}{$\begin{array}{l}\text { Genotypic } \\
\text { variance }\end{array}$} & \multicolumn{2}{|c|}{$\begin{array}{c}\text { Phenotypic } \\
\text { variance }\end{array}$} & \multicolumn{2}{|c|}{$\begin{array}{c}\text { Genotypic } \\
\text { coefficient of } \\
\text { variation }\end{array}$} & \multicolumn{2}{|c|}{$\begin{array}{c}\text { Phenotypic } \\
\text { coefficient of } \\
\text { variation }\end{array}$} & \multicolumn{2}{|c|}{$\begin{array}{l}\text { Heritability } \\
\text { (broadsense) }\end{array}$} & \multicolumn{2}{|c|}{ Genetic advance } & \multicolumn{2}{|c|}{$\begin{array}{l}\text { Genetic advance } \\
\text { as percent mean }\end{array}$} \\
\hline & & Irrigated & Stress & Irrigated & Stress & Irrigated & Stress & Irrigated & Stress & Irrigated & Stress & Irrigated & Stress & Irrigated & Stress \\
\hline 1 & Days to $50 \%$ flowering & 3.62 & 3.77 & 10.95 & 10.92 & 2.13 & 2.28 & 3.71 & 3.89 & 33.1 & 34.53 & 2.26 & 2.35 & 2.53 & 2.77 \\
\hline 2 & Days to maturity & 3.39 & 5.85 & 17 & 11.4 & 1.56 & 2.11 & 3.49 & 2.95 & 19.94 & 51.35 & 1.69 & 3.57 & 1.43 & 3.12 \\
\hline 3 & Effective tillers/hill till & 1 & 0.4 & 1.35 & 0.82 & 11.81 & 8.02 & 13.73 & 11.46 & 74.05 & 48.97 & 1.78 & 0.91 & 20.94 & 11.56 \\
\hline 4 & Plant height $(\mathrm{cm})$ & 41.51 & 48.51 & 74.19 & 111.4 & 6.27 & 7.12 & 8.38 & 10.8 & 55.96 & 43.54 & 9.93 & 9.47 & 9.66 & 9.68 \\
\hline 5 & Panicle length $(\mathrm{cm})$ & 1.84 & 2.3 & 3.85 & 4.46 & 5.08 & 5.82 & 7.35 & 8.12 & 47.79 & 51.43 & 1.93 & 2.24 & 7.24 & 8.6 \\
\hline 6 & Fertile grains per panicle & 345.87 & 177.96 & 437.16 & 225.5 & 15.42 & 13.64 & 17.34 & 15.36 & 79.12 & 78.92 & 34.08 & 24.41 & 28.26 & 24.97 \\
\hline 7 & Sterile grains per panicle & 29.7 & 42.89 & 33.01 & 47.59 & 37.42 & 31.97 & 39.44 & 33.68 & 89.99 & 90.14 & 10.65 & 12.81 & 73.12 & 62.53 \\
\hline 8 & Sterility (\%) & 12.71 & 19.38 & 14.99 & 22.54 & 33.03 & 25.6 & 35.87 & 27.61 & 84.8 & 85.98 & 6.76 & 8.41 & 62.66 & 48.9 \\
\hline 9 & Total no. of spikelets/panicle & 408.79 & 272.33 & 501.33 & 323.78 & 14.96 & 13.95 & 16.56 & 15.22 & 81.57 & 84.11 & 37.62 & 31.18 & 27.84 & 26.36 \\
\hline 10 & Panicle density index & 0.58 & 0.39 & 0.81 & 0.58 & 14.98 & 13.59 & 17.7 & 16.66 & 71.66 & 66.61 & 1.33 & 1.05 & 26.12 & 22.86 \\
\hline 11 & 1000-grain weight (g) & 4.18 & 3.29 & 5.56 & 5.12 & 8.03 & 8.56 & 9.26 & 10.67 & 75.2 & 64.34 & 3.65 & 3.00 & 14.35 & 14.15 \\
\hline 12 & Biological yield (g) & 11.29 & 6.67 & 23.36 & 19.44 & 7.46 & 6.39 & 10.73 & 10.91 & 48.33 & 34.32 & 4.81 & 3.12 & 10.68 & 7.71 \\
\hline 13 & Harvesting index (\%) & 2.68 & 11.04 & 13.73 & 34.86 & 3.37 & 8.31 & 7.63 & 14.77 & 19.5 & 31.66 & 1.49 & 3.85 & 3.06 & 9.63 \\
\hline 14 & Leaf area $\left(\mathrm{cm}^{2}\right)$ & 35.84 & 39.44 & 38.83 & 41.16 & 22.58 & 30.5 & 23.51 & 31.16 & 92.29 & 95.81 & 11.85 & 12.66 & 44.69 & 61.5 \\
\hline 15 & Relative water content & 14.36 & 12.96 & 17.33 & 13.61 & 4.31 & 4.92 & 4.74 & 5.04 & 82.83 & 95.22 & 7.10 & 7.24 & 8.09 & 9.89 \\
\hline 16 & Proline & 2.31 & 2.33 & 2.62 & 2.81 & 4.64 & 3.45 & 4.94 & 3.79 & 88.06 & 83.01 & 2.94 & 2.86 & 8.96 & 6.48 \\
\hline 17 & Root biomass & 21 & 9.22 & 24.5 & 11.15 & 23.15 & 21.93 & 25.01 & 24.12 & 85.71 & 82.65 & 8.74 & 5.69 & 44.15 & 41.07 \\
\hline 18 & Chlorophyll index & 4.64 & 3.75 & 17.34 & 6.41 & 4.82 & 4.65 & 9.3 & 6.09 & 26.79 & 58.42 & 2.3 & 3.05 & 5.13 & 7.33 \\
\hline 19 & Grain yield/ plant (g) & 5.78 & 3.91 & 9.36 & 5.38 & 9.87 & 12.31 & 12.56 & 14.44 & 61.77 & 72.67 & 3.89 & 3.47 & 15.98 & 21.62 \\
\hline
\end{tabular}


In the present investigation, high heritability coupled with high genetic advance over mean was observed for fertile grains per panicle, total grains per panicle, panicle density index, leaf area and root biomass in irrigated as well as drought stress condition which suggested that these characters can be considered as favorable attributes for improvement through selection and this may be due to presence of additive genes effect and thus, could be improved upon by adopting selection without progeny testing. Hence, direct selection can be done through these characters for future improvement of genotypes under respective environments for improvement of drought tolerance and higher grain yield. Similar results were also reported by earlier workers viz., Muthuswamy et al., (2006),Manickavelu et al., (2006) and Gomez et al., (2003). The high heritability associated with high genetic advance indicated that the variation was mostly due to additive gene effects. It indicates that if these characters are subjected to any selection scheme for exploiting fixable genetic variance, a widely adapted genotype can be developed.

The present studies suggested the existence of variation among the genotypes for grain yield and yield contributing morpho-physiological traits which showed differential response to drought stress environment at reproductive stage. Drought stress at reproductive stage caused significant reduction in plant height, grain yield, relative water content (\%) and increase in proline and grain sterility percentage in rice genotypes; however, the responses varied among genotype. Further yield improvements in drought stress situation can be achieved by identifying morphophysiological traits contributing for tolerance against water stress.

\section{References}

Allah, A.A.A. 2009. Genetic studies on leaf rolling and some root traits under drought conditions in rice (Oryza sativa L.). African J of Biotech.8 (22) : 624148.

Blum, A 1988. Plant breeding for stress environments. CRC press inc. Florida, USA. PP. 43-77.

Chen, FengMei., Long, YuanMei., Cheng,JianFeng., Pan, XiaoYun and Liu,YiBai.2001. Genetic analysis of the drought-resistant indices in indica rice.ActaAgricUniversitatisJiangxiensis 23 (1): 41-45

El-Ashmoony, M.S.F., El-Sherbeny, A.A. and Amin, I.A. 2004.Breeding for drought tolerance and the association of grain yield and other traits of bread wheat.Egyptian J. Agric. Res. 82(3): 1227-41.

El-Kareem, T.H.A.A. and El-Saidy, A.E.A. 2011. Evaluation of yield and grain quality of some bread wheat genotypes under normal and drought stress conditions in calcareous soils. J. Biol. Sci. $11: 156-64$

Ganapathy, S., Ganesh, S.K., Vivekanandan, P., Shanmugasundaram, $\mathrm{P}$ and Babu, R. C.2007. Variability and interrelationship between yield and physio-morphological traits in rice (Oryza sativa L.) under moisture stress condition. Crop Res.34(1/3): 260-262

Gomez, S.M and Kalamani, A. 2003.Scope of landraces for future drought tolerance breeding programme in rice (Oryza sativa L.).Plant Archives3(1): 77- 79

Johnson, H. W., Robinson, H. F. and Comstock, R. E. 1955.Estimates of genetic and environmental variability in soyabeans.Agron. J.47:314-318.

Kour S. and Pradhan U.K. 2016. Correlation, path coefficient analysis and construction of indices for yield and yield components selection in forage sorghum [Sorghum bicolor (L) Moench]. $J$ of Crop and Weed, 


$$
\text { 12(2):01-09 }
$$

Lonbani, M. and Arzani, A. 2011.Morphophysiological traits associated with terminal drought-stress tolerance in triticale and wheat. Agronomy Res.9 (1/2): 315-329

Manickavelu, A., Gnanamalar, R.P., Nadarajan, N and Ganesh, S.K. 2006. Genetic variability studies on different genetic populations of rice under drought condition. J. Pl. Sci.1(4): 332339

Manickavelu, A., Nadarajan, N., Ganesh, S.K. and Gnanamalar, R.P. 2006. Genetic analysis of biparental progenies in rice (Oryza sativa L.). Asian J. Pl. Sci. 5(1): 33-36.

Mina, Abarshah., Babak, Rabiei, Habibollah and Samizadeh, lahigi. 2011. Assessing Genetic Diversity of Rice Varieties under Drought Stress Conditions. NotulaeScientiaBiologicae, 3(1) : 11423.

Muthuswamy, A and Kumar, C. R. A. 2006. Variability studies in drought resistant cultivars of rice. Res. on Crops.7(1): 130-132

Ouk, M., Basnayake, J., Tsubo, M., Fukai, S., Fischer, K.S., Cooper, $M$ and Nesbitt, H. 2006.Use of drought response index for identification of drought tolerant genotypes in rainfed lowland rice.Field Crops Res.99(1): 48-58

Padulosi S. 1993. Genetic diversity, taxonomy, and eco-geographical survey of the wild relatives of cowpea (Vignauniguiculata L. Walp).Ph.D Thesis

Pantuwan, G., Fukai, S., Cooper, M., Rajatasereekul, S and O'Toole, J.C. 2002. Yield response of rice (Oryza sativa L.) genotypes to drought under rainfed lowlands. 2. Selection of drought resistant genotypes. Field Crops Res.73(2/3): 169-180

Pantuwan,G., Fukai, S., Cooper, M., Rajatasereekul, S., O'Toole, J.C and Basnayake, J. 2004. Yield response of rice ( Oryza sativa L.) genotypes to drought under rainfed lowlands. 4. Vegetative stage screening in the dry season. Field Crops Res. 89(2/3) : 281297

Saravanan, R. and Senthil, N. 1997.Genotypic and phenotypic variability, heritability and genetic advance in some important traits in rice.Madras Agric. J.84: 27677.

Venkataramana, P and Shailaja, H. 1999. Genetic variability on some important traits in two F2segregants of rice (Oryza sativa L.) under non-submergence condition.Crop Res. 18(1): 53- 56

Wu Ming Guo., Lin, J. R. and Zhang, G. H. 2004.Genetic analysis of leaf relative water content in paddy upland hybrid rice.Chinese J. Rice Sci.18(6): 570572.-26.

\section{How to cite this article:}

Sadia Perween, Anand Kumar, S. P. Singh, Satyendra, Mankesh Kumar and Ravi Ranjan Kumar. 2020. Genetic Variability Parameters for Yield and Yield Related Traits in Rice (Oryza sativa L.) under Irrigated and Drought Stress Condition. Int.J.Curr.Microbiol.App.Sci. 9(02): 1137-1143. doi: https://doi.org/10.20546/ijcmas.2020.902.133 